\title{
A randomised enquiry on the interaction between Wellbeing and Citizenship
}

\author{
Alicia Georghiades ${ }^{1}$, Francisco Jose Eiroa-Orosa ${ }^{1,2}$
}

1. Section of Personality, Assessment and Psychological Treatment, Department of Clinical Psychology and Psychobiology, Institute of Neuroscience, University of Barcelona. Passeig Vall d'Hebron, 171, 08035 Barcelona

2. Yale Program for Recovery and Community Health (PRCH), Department of Psychiatry, Yale School of Medicine. Erector Square, Bldg One, 319 Peck Street, New Haven CT

Correspondence:

Francisco José Eiroa-Orosa

fjeiroa@gmail.com 


\begin{abstract}
Wellbeing and citizenship have been outlined as important components for personal flourishing and involvement in community life. The Community Engagement Project aimed to identify the strength of the relationship between wellbeing and citizenship. In addition, the study aimed to investigate the capability of changing wellbeing and citizenship levels over time after exposure to a short experiment which also involved the following variables; Social Justice Beliefs, Assertiveness, Justice and Care Values. An intervention research design was implemented with a self-selected sample; 28 participants from the experimental group and 24 participants from the control group completed the final follow-up. Correlational results supported our first hypothesis as a statistically significant positive relationship was found between all the citizenship and wellbeing subscales. Support was found for within group differences for Personal Responsibility and Social Justice Beliefs indicating that this short experiment was able to influence these variables from pre to post. The repeated measures analysis of variance (RM-ANOVA) demonstrated that when considering time and condition the subjective perception of greater Legal Rights increased after the experiment only for the intervention group. Professionals could use the findings to provide a platform for vulnerable groups by providing the resources to be more assertive which could improve overall wellbeing and sense of citizenship.
\end{abstract}

Key words: Active Citizenship, Wellbeing, Social Justice, Assertiveness, Values 


\section{A randomised enquiry on the interaction between Wellbeing and Citizenship}

\section{Introduction}

\section{Active Citizenship and Community Engagement}

Citizenship has been defined as a measure of the strength of an individuals' connections to their rights, responsibilities, roles, resources and relationships that society offers them through public and social institutions (Michael Rowe, 1999; Michael Rowe, Kloos, Chinman, Davidson, \& Cross, 2001). Full citizenship refers to the privileges provided by members of a democratic society and to the responsibilities these rights engender. Participation in rights versus passive legal and social rights have been found to motivate individuals to improve the well-being of their communities whilst simultaneously enhancing their own development (Janoski, 1998; Zaff, Boyd, Li, Lerner, \& Lerner, 2010).

Historically, the rights of individuals with physical and/or social disadvantages have been neglected. For instance, the rights of people diagnosed with mental illnesses were restricted on the grounds of mental incompetencies due to 'labelling', hospitalisation or other factors which led to them being characterised as 'second class' citizens. Among some members of the latter group, the combination of mental health and extreme social exclusion has led to a further deterioration of rights with many individuals falling into the category of 'noncitizenship'. Homeless people may fall into the 'non-citizenship' category due to their lack of contact with mainstream society and the stigma that is still associated with homelessness (Michael Rowe, 1999). Active citizenship, a term that involves a proactive attitude towards the use of rights and the engagement with responsibilities, has also been associated with relationship building and role achievement (Rowe, Benedict, Sells, \& Dinzeo, 2009). Reciprocal interpersonal relationships enable the individual to identify with a larger group, such as being part of a community, which in turn provides access to resources. The process of 
expanding citizenship rights, for example by volunteering, engaging in community groups or being involved in organisations that fight for injustices has many psychological benefits (Flanagan \& Levine, 2010). This has been linked to positive identity development, fulfillment, self-efficacy, increased social connection and enhanced communication skills (Dolan, 2010; Kendrick Jr, 1996; Sherrod, Flanagan, \& Youniss, 2010; Tucker \& McCarthy, 2001; Youniss, McLellan, \& Yates, 1997). Engagement in community services has been found to initiate an involvement in social and political attitudes which in turn could lead to political development (Fyfe \& Milligan, 2003; Haste, 2004; Sherrod, Flanagan, \& Youniss, 2002). Referring back to the example of individuals diagnosed with mental disorders, by merely providing them with the resources to participate in elections and allowing them to vote has been found to be a powerful method of enabling them to express their citizenship rights (Chan \& Chiu, 2007). Additionally fighting for injustices, such as through the use of activism, has not only been linked to improved levels of well-being but has also led to a sense of empowerment (Gilster, 2012; Montague \& Eiroa-Orosa, 2017, 2018). Therefore, practices that initiate greater participation in community activities have the ability to empower the individual and lead to better overall wellbeing (Weddington, 1995).

\section{Social Justice}

Social Justice has been defined as the fair and equitable allocation of resources, rights, and treatment of marginalised individuals who do not share equal power in society (Fondacaro \& Weinberg, 2002; Prilleltensky \& Nelson, 1997).

Early paradigms of social justice such as the 'Libertarian Justice Model' by John Locke emphasised the connection between merit and liberty, this is based on the idea that the acquisition of resources do not need to be equitable but they should occur fairly and reflect what is deserved or entitled regardless of individual differences (Nozick, 1974). Therefore, any 
multicultural movement that underemphasizes social justice is unlikely to eradicate oppression and will maintain the status quo (Vera \& Speight, 2003). Individuals who believe that there is social justice, for example they have strong 'Beliefs in a Just World' (BJW) are more likely to support the status quo, that is that if the world is just then the distributions of wealth in a society should and must be maintained (Dittmar \& Dickinson, 1993). Previous research has demonstrated a strong link between BJW and wellbeing, as the perceptions of fairness and (in)justice have been linked to health and mental health outcomes (i.e. depression) (Furnham, 2003; Jiang, Yue, Lu, Yu, \& Zhu, 2016). Individuals with high BJW are more likely to have greater life satisfaction and use it as a coping mechanism against the stresses of acknowledging injustice (Dalbert, 2001; Lipkusa, Dalbert, \& Siegler, 1996). On the other hand, research has found that BJW provides a rationale for inaction, even among disadvantaged groups, because of the belief that people will eventually receive the rewards they deserve (Stroebe, 2013).

How could social justice be promoted? According to the contact hypothesis if individuals identify with particular groups in conflict they have the opportunity to reevalute the relationship they have with that group and eliminate negative stereotypes (Allport, 1954). However, the contact hypothesis has been insufficient in explaining the way in which people achieve social justice and change. Direct services such as advocacy, outreach prevention programs, public policy and psychoeducational interventions have been found to be effective in promoting social justice (Bemak \& Chung, 2005; Ginwright \& James, 2002; Kiselica \& Robinson, 2001; Ratts, Singh, Nassar-McMillan, Butler, \& McCullough, 2016).

\section{Assertiveness}

Assertiveness has been described as the ability to express oneself without anxiety or aggression in different situations (Bouvard et al., 1999). Behaviours considered low in assertiveness (i.e. avoidance and anxiety) can lead to worse material or instrumental outcomes, 
as well as a failure to receive resources and support (Ames, Lee, \& Wazlawek, 2017). Additionally this has also been linked to neuroticism, depression and psychosomatic complaints (Rushton, Fulker, Neale, Nias, \& Eysenck, 1989; Thompson \& Berenbaum, 2011). Unassertive behaviour may arise from the mistaken belief that one does not have the right to act assertively, or the belief that certain rights are denied due to one's gender or position in society (Lange \& Jakubowski, 1978).

In contrast, high levels of assertiveness (i.e. competition and aggression) have been linked to compliance and the attainment of one's rights. However, these aggressive responses can result in greater anger and hostility which may only be effective in the short term. This is because they can hinder relationships, lead to stress and diminish health and well-being (Ames \& Flynn, 2007; Aubé, 2007). Therefore, assertiveness is required to achieve equity in human relationships and to exercise personal rights without denying the rights of others (Alberti \& Emmons, 1995). While it is true that citizens in the world's richest countries are more willing to make demands and engage in the delivery of public services, this is still dominated by the better educated and wealthier middle class. Increased assertiveness and user engagement are key in securing better outcomes, however it is important to consider the barriers that may prevent users from gaining access to the highest quality of service delivery (Griffiths, Foley, \& Prendergrast, 2009).

How can we increase assertiveness for disadvantaged groups? Training individuals to develop their assertiveness skills has led to a number of health benefits such as an increase in self-esteem, life satisfaction and a reduction in interpersonal conflict. Additionally, this has been linked to the obtainment of one's own rights and the advocacy of the rights of others (e.g. Ahmadi, Daramadi, Asadi-Samani, Givtaj, \& Sani, 2017; Chan, 1993; Rathus, 1972).

\section{Justice and Care Values}


Justice and Care Values (hereafter referred to as 'values') relates to an individual's moral development which is the replacement of the internalisation of societal standards to cognition and action which have been developed to benefit others (Nelson, Prilleltensky, \& Macgillivary, 2001). As a result, individuals do not only do the right thing for the sake of social conformity or expectations from authority figures, but instead the individual has developed concerns and an awareness of moral conduct which is implemented in a wide range of situations and in the society they live in (Habib, 2011).

Discussions about moral development involve the contributions that have been made by Piaget who focused on the way in which morality developed in children as a means of understanding adult morality. Piaget viewed the development of a child's moral judgement as a shift from the heteronomous stage to the autonomous stage which consists of the emergence of moral concepts such as justice and rights (Ruffy, 1981).

Previous work has outlined that values are required in order to build solidarity with disadvantaged groups, as well as promote the well-being of these groups which benefits individuals and communities (Kekes, 1993). Justice is a value that guides the fair and equitable allocation of resources and burdens in society. For example, in order to achieve selfdetermination and have a high level of well-being the presence of financial and material resources need to be available, as well as tangible resources such as education, employment, income and housing (Nelson, Walsh-Bowers \& Hall, 1998; Prilleltensky \& Nelson, 1997). Whereas care and compassion provide the motivation to look after someone else's wellbeing in the form of concern for the physical and psychological health of others such as caring for the elderly (Nelson et al., 2001; Swanson, 2010).

How can justice and care be encouraged in society? Community psychologists have helped to promote justice and care by forming partnerships with oppressed groups (such as 
families living in poverty). This is due to mainstream organisations holding contrasting values and often blaming the victims for not 'fitting in' (Reinharz, 1984; Ryan, 1976). These settings are firmly based on the values of care and mutual support which focus on the enhancement of well-being and power sharing. The process of creating alternative settings such as crisis for women and self-help organisations have enabled a greater power distribution and has helped to create a value-based partnership. This could be encouraged further by rotating leadership responsibilities such as having individuals from disadvantaged groups chair meetings and give presentations about the projects that they have been involved in, which has the potential to enhance the participation of citizens and redistribute power (Nelson et al., 2001). On the other hand, justice could be promoted by providing tangible resources which could help to break down barriers for disadvantaged groups and allow them to participate in society. However, in order to achieve justice it is necessary to provide the resources to be an active citizen as oppose to merely redistributing resources. Nelson, Ochocka, Griffin, \& Lord (1998) discussed the importance of hiring and training people from oppressed groups, in order for them to be able to gain access to education, employment, and income.

Active participation of citizens and providing oppressed individuals with a "voice" in society is an essential part of enabling citizen participation for different groups. For example, enabling disadvantaged groups to be involved in decision-making in prevention programs, provides them with a meaningful way to be involved as opposed to token participation (Cameron, Peirson, \& Pancer, 2009; Church, 1995; Valentine \& Capponi, 1989). This helps to build relationships and trust, establish norms and principles for working together, as well as sharing power and resources which are key processes for value-based partnerships (Nelson et al., 2001). This is important as partnerships with oppressed groups that do not have clear values run the risk of maintaining the status quo (Prilleltensky, 1994). 


\section{Study Aims}

We aim to investigate the relationship between wellbeing and sense of citizenship. We also aim to analyse if this relation is influenced by variables such as 'Social Justice Beliefs', 'Assertiveness' and 'Values'. Furthermore, we wanted measure all of these variables and to test the temporal stability and susceptibility to change after taking part in an experiment which tried to increase social awareness.

\section{Research questions and hypotheses}

According to the aforementioned aims of the study, we had the following research questions and hypotheses.

Our first research question focused on the relationship between wellbeing and citizenship. We aimed to measure the correlations and identify possible modificators of these variables. Our hypothesis was that wellbeing and sense of citizenship are correlated (H1a) and their relation is possibly altered by 'Social Justice Beliefs', 'Assertiveness' and 'Values' (H1b). An intervention conducted on individuals receiving public mental health services found a relationship between citizenship, wellbeing and assertiveness. This citizenship intervention involved a group component which focused on assertiveness training, problem solving, relationship building and valued roles. The findings demonstrated that there was an enhancement in the amount of satisfaction related to social activity, finances and work. Additionally an improvement was found in the individual's quality of life (Clayton, O'Connell, Bellamy, Benedict, \& Rowe, 2013; Michael Rowe \& Pelletier, 2012). Support has also been found for a link between beliefs in a just world and higher levels of wellbeing. BJW has been found to contribute to subjective well-being as it increases one's sense of control and enables individuals to cope more adaptively with negative life events, BJW has also been linked to psychological wellbeing and greater life satisfaction (Lipkusa et al., 1996). Research has found 
a relationship between wellbeing and values as subjective wellbeing may be associated with emphasizing particular values such as compassion as opposed to others such as, security (Sagiv \& Schwartz, 2000). Additionally values that emphasize personal autonomy, freedom of expression and equality of opportunities should potentially bring more satisfaction (Welzel \& Inglehart, 2010). These variables will be measured within an experiment as which is outlined below.

Our second research question is related to the stability of wellbeing and citizenship over time. We wanted to find out if doing a short experiment designed by our study group could change the subjective view of wellbeing, citizenship and their relation. Our second hypothesis is that the levels of citizenship and wellbeing could be altered (H2) by implementing a short experiment focusing on the awareness of the aforementioned variables, i.e. Social Justice Beliefs, Assertiveness and Values (whose evolution will also be tested). This will be tested within and between groups. Within groups interactions (expecting change after the experiment, $\mathrm{H} 2 \mathrm{a})$ will be tested taking both groups together and testing pre-post differences. Between groups interactions (expecting differences among groups, with higher levels for the experimental group, $\mathrm{H} 2 \mathrm{~b}$ ) will be tested after using a wait-list controlled randomised design, in which $50 \%$ of people participating will be randomised to an experimental group and the rest to a wait-list group. The latter group will then be offered the opportunity to go through the same experiment after one week. Both groups will be followed-up one week after the experiment. Interactions between time and experimental group (expecting time by group interactions, $\mathrm{H} 2 \mathrm{c}$ ) will also be tested. 


\section{Methods}

\section{Participants}

The study aimed to recruit participants using a self-selected sampling method. For this reason participants were recruited using social network sites and forums over a period of four months. The participants were informed that the study aimed to deepen their knowledge of the influence of citizenship on wellbeing. In order to take part in the study, the participants had to be 16 or over and have a high comprehension of English.

$\begin{array}{llll}\text { Sample } & \text { size } & \text { walculated } & \text { Gsing }\end{array}$ (https://www.imim.cat/ofertadeserveis/software-public/granmo). The calculation was done taking into account hypothesis H2a. Accepting an alpha risk of 0.05 and a beta risk of 0.2 in a two-sided test, 63 subjects would be necessary in each group to recognize a statistically significant difference greater than or equal to 0.5 standard deviations.

Although a total of 242 people were enrolled in the study, 60 participants did not finish the baseline and therefore could not be included in any analysis (see figure 1). Of the remaining 182 participants who had completed stage one, 175 continued to randomisation. From the latter, 84 were allocated to the experimental condition and 91 were allocated to the control condition. Due to attrition, the number completing the follow-up from the experimental group reduced to 28 and for the control group this reduced to 24 . 
Figure 1. CONSORT flow diagram

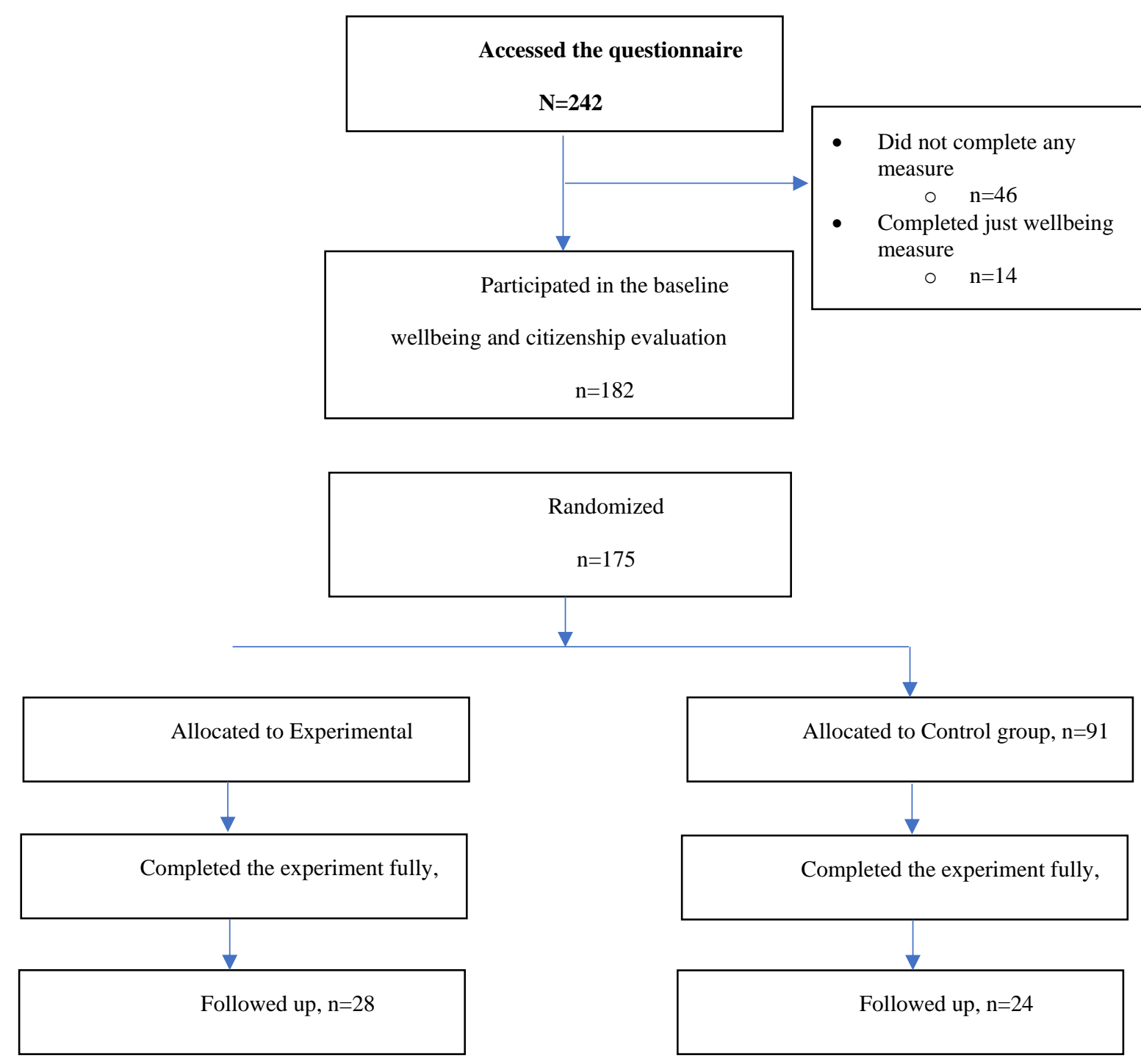




\section{Procedure}

The participants used the online Qualtrics platform (https://www.qualtrics.com/) to complete the 'Community Engagement Project', which involved providing them with information and a consent form to participate in the study.

All consenting participants were directed to the baseline survey which involved answering the wellbeing and citizenship subscales and sociodemographic questions (i.e. age, gender, place of origin, etc.). At the end of the baseline, with the option of refusing to do so, participants provided their email address. This was essential in order to be able to access the next sections of the study, as an embedded link was included in the email reminders which were sent automatically by the Qualtrics platform. The participants were then allocated at random to either the wait list-control or the experimental condition. At each stage after completing the baseline measures, both participant groups were provided with their overall wellbeing and citizenship score in order to inform the participant of their progress. A CONSORT flow chart including the number of participants allocated to each condition, followed up and analysed can be seen in figure 1. Figure 2 shows a schema of the experimental allocation and flowchart.

After taking the baseline survey the participants in the experimental condition were directed immediately to the short experiment which involved watching a series of videos and answering questions related to 'Social Justice Beliefs', 'Assertiveness' and 'Values'. At time 2, which was approximately one week after the baseline, the experimental group took part in the follow-up which involved reassessing their wellbeing and citizenship levels using the same subscales presented during the baseline assessment. Additionally, at time 2 the participants reanswered questions related to 'Social Justice Beliefs', 'Assertiveness' and 'Values' which had originally been presented during the experiment. This was in order to identify whether their wellbeing and citizenship levels had changed after taking part in the short experiment. 
Figure 2. Flow diagram of the experiment

TIME 1

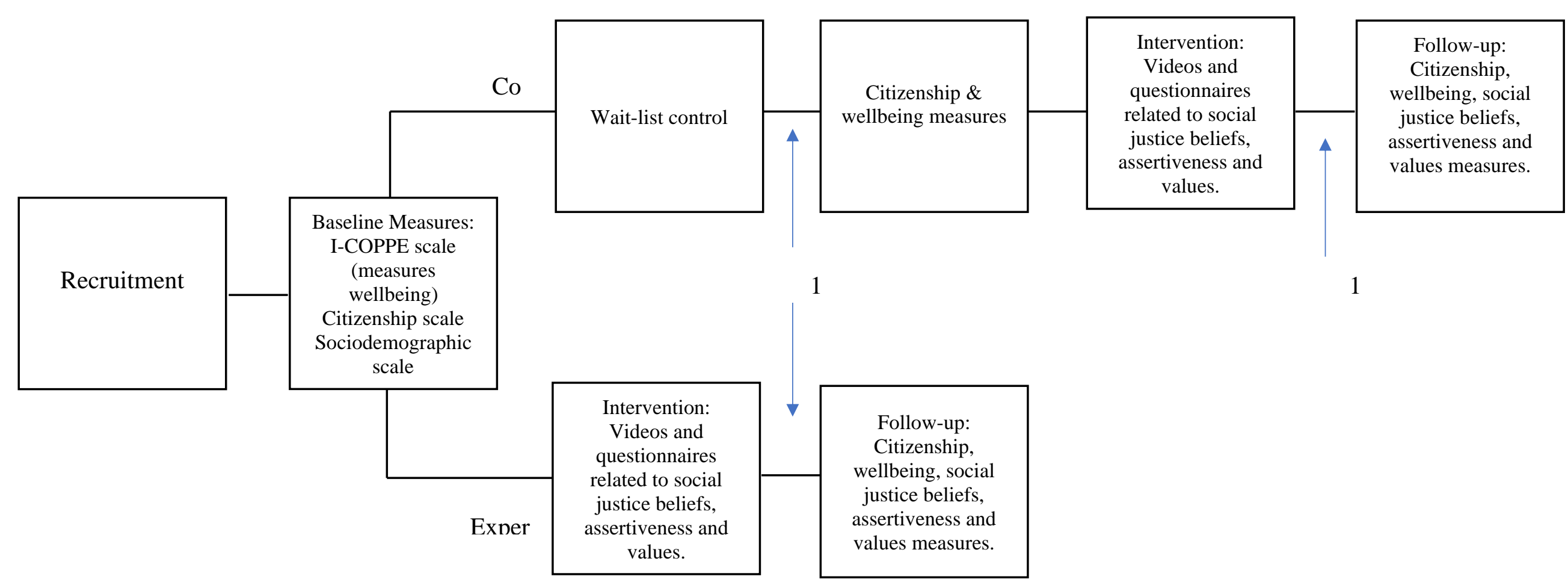


In contrast the control group were only given the baseline subscales and were then informed that they had to wait for approximately a week to receive the second part of the study. Email reminders were sent out in order to prompt participants to complete the short experiment. At time 2, which was approximately one week later, they were re-evaluated on the citizenship and wellbeing subscales before being diverted to the short experiment involving the same videos that had been presented to the experimental group (i.e. related to Social Justice Beliefs, Assertiveness and Values). Lastly at time 3, which was approximately one week after the experiment, the control group received the follow-up which involved reassessing their opinions related to wellbeing, citizenship, 'Social Justice Beliefs', 'Assertiveness' and 'Values'. After the participants in each condition completed the Community Engagement Project they were thanked for their time and participation.

The online questionnaire was structured in a way that facilitated participation in our cross-sectional inquiry on the relationship between wellbeing and citizenship and their possible modificators as these themes were embedded in the experiment with the aim of raising awareness on all these issues. All the measures and activities used can be found in the measures and experimental procedures sections, mirroring the structure in which they were presented to participants.

The study was approved by the Bioethics Committee at the University of Barcelona (Institutional Review Board: IRB 00003099).

\section{Experimental design.}

\section{Active Citizenship experiment.}

This involved a video outlining the importance of citizen participation and overall wellbeing. The video promoted the five R's; Rights, Responsibilities, Roles, Resources and 
Relationships (Michael Rowe \& Pelletier, 2012). Promoting the five R's is important as it gives meaning to our lives and helps to build identities.

\section{Social Justice Experiment.}

Immediately after completing the Social Justice Beliefs questionnaire, a video was presented which described the lives of two individuals; Richard and Paula. This provided the story of how it is not so easy to be successful if you do not have the right opportunities and you do not come from a privileged background. After watching the video, the participants were presented with open questions which were 'In your opinion would you say that everyone has the same opportunities regardless of their social class? If you work hard can you still achieve the same education and job opportunities?'.

\section{Assertiveness experiment.}

After completing the questionnaire, the participant was presented with a video related to assertiveness (https://www.youtube.com/watch?v=5tqu6r4Bmj8) which describes the benefits of being assertive as it has been associated with more positive relationships, group harmony and greater wellbeing.

\section{Justice and Care Values experiment.}

The last section of the experiment was divided into two different types of values; justice and care. The participant was shown a moral judgement vignette (Habib, 2011) which was based on a moral situation. This described the story of a young boy from a disadvantaged background who was contemplating shoplifting in order to help his sick brother.

\section{Measures}

I Coppe Scale (Prilleltensky et al., 2015). The I Coppe Scale is a self-anchoring method using a likert scale that measures subjective life experiences with a range of 0 "worst" to 10 "best". This refers to the respondent's levels of satisfaction based on present, past and future 
experiences (Cantril, 1965). Strong psychometric evidence of validity and reliability have been documented for this self-anchoring method by wellbeing researchers (Prilleltensky et al., 2015). Overall the cronbach alpha in our study was high for this questionnaire $(\alpha=.947)$. The I Coppe scale consists of 21 items which assess the underlying constructs of wellbeing; Overall Life, Interpersonal, Community, Occupational, Physical health, Psychological and Economic factors. The term overall wellbeing refers to the subjective perception of the individual's state of affairs, for example "When it comes to the best possible life for you, on which number do you stand now?'. Interpersonal wellbeing refers to the quality of relationships that an individual has with friends, family and colleagues, such as "When it comes to relationships with important people in your life, on which number did you stand a year ago?". Community wellbeing refers to satisfaction with one's community "When it comes to the community where you live, on which number do you think you will stand a year from now". Occupational wellbeing refers to satisfaction with one's job or vocation. Physical wellbeing refers to satisfaction with overall health and wellness. Psychological wellbeing refers to satisfaction with one's emotional life and Economic wellbeing relates to satisfaction with one's financial situation.

Citizenship Measure (Rowe et al., 2012). The Citizenship measure, originally proposed by Rowe et al (2012), consists of 45 questions based on the five R's; Rights, Responsibilities, Roles, Resources and Relationships. These items were further divided into seven domains; Personal Responsibility, Government \& Infrastructure, Caring for self \& others, Civil Rights, Legal Rights, Choice and World Stewardship. An example item includes, 'Thinking about your life in general right now, please read each statement and rate on a scale of 1 to 5 how much you feel that the statement applies to you... Your personal decisions and choices are respected' which in this case relates to the choice domain. The instrument was able to capture subjective information regarding the individual's experiences using a likert scale ranging from 1 "Not at 
all/Never" to 5 "A lot/Very Often". Analyses of the citizenship measure have illustrated that the measure is psychometrically sound (O’Connell, Clayton, \& Rowe, 2016). Overall in this study the Cronbach's alpha for this scale indicated that it had good internal consistency $(\alpha=.946)$

\section{Demographics.}

A questionnaire consisting of ten items related to gender, age, background, country of origin, country of residence, relationship status, educational qualifications, occupation and social class. Additionally two ideology questions on materialism/postmaterialism and traditionalism-secularism were included; 'Government should ensure that everyone is provided for' and 'A child needs a home with both a father and a mother in order to grow up happily' (Inglehart, Basanez, \& Diez-Medrano, 2000). The latter were operationalised using a likert scale which provide six options ranging from 'strongly agree' to 'strongly disagree'.

Social Justice Beliefs measure (Dalbert, 2000). The concept of 'Social Justice' was measured using the Belief in a Just World questionnaire. This is a six-item questionnaire related to the concept of justice 'I believe that, by and large, people get what they deserve' and injustices 'I am convinced that in the long run people will be compensated for injustices'. Participants had to rate themselves on a Likert scale ranging from 1 (strongly disagree) to 6 (strongly agree). The reliability and construct validity of the questionnaire has been approved in different studies (Ambrosio \& Sheehan, 1990; Caputi, 1994; Couch, 1998; Mohr \& Luscri, 1995; O'Quin \& Vogler, 1990; Whatley, 1993). The reliability of the questionnaire has been reported to be 0.672 and 0.678 for belief in a just and unjust world (Roshani, Jalili, \& Adaryani, 2013). In the current study, a good Cronbach alpha was found for this questionnaire $(\alpha=.846)$.

Assertiveness scale (Thompson \& Berenbaum, 2011). Assertiveness was tested using the Adaptive and Aggressive Assertiveness Scale (AAA-S) which involved 19 hypothetical situations which reflected adaptive and aggressive assertiveness. Participants had to indicate 
the extent to which they would react to a given situation using a scale of 1 (never) to 5 (always). An example of a hypothetical question related to aggressive assertiveness was "When someone close to me unjustly criticizes my behaviour, I... - b. React angrily and tell the person that she/he shouldn't be throwing stones", whereas an example of an assertiveness question "It has been over a year since I received a promotion, I... - a. Ask my boss about getting a promotion”. This assertiveness scale was chosen due to displaying good internal consistency, split-half reliability, when employing the Spearman-Brown correction, and a 2-week test-retest reliability (Thompson \& Berenbaum, 2011). As reiterated previously, this questionnaire demonstrated a good Cronbach alpha $(\alpha=.866)$.

\section{Justice and Care Values Scale (Gump et al.2000).}

The participant was first presented with a few open questions such as 'Do you think doing the right thing is always easy? Are there times when it is acceptable not to do the right thing?'. After answering these questions and seeing the vignette the participant completed the 'Moral Justification Scale' (Gump, Baker, \& Roll, 2000) which consisted of a Likert scale ranging from 1 (not at all important) to 10 (very important). These statements related to 'Justice' values "The amount his parents had been overcharged was nearly the same as the price of the coat. Tony felt it was only fair that he take the coat since the store really owed it to his family anyway" and 'Care' values "Tony could not bear seeing his fragile-looking younger brother suffer, for the little boy was already sick with the flu and could easily catch pneumonia". The 'Justice and Care' values scale has displayed good internal consistency as when a test-retest method was used to measure the reliability of the scale, this was found to be 0.99 . Content validity of the scale indicates the appropriateness of each dilemma (Habib, 2011). There is a good Cronbach alpha for this questionnaire $(\alpha=.723)$. 


\section{Data analysis}

T-tests and Chi-squared tests with odds ratios were used to compare socio-demographic characteristics between the experimental and control group and to compare baseline scores of participants completing the first follow-up with those who did not. The normality of variance was checked using skewness and kurtosis parametres. Pearson correlation matrices were conducted in order to test the relationship between wellbeing, citizenship and their possible modificators; 'Social Justice Beliefs', 'Assertiveness' and 'Values'. A paired samples t-test was conducted to test within group differences pre and post experiment. Independent samples t-tests were used to test group differences between the conditions; control and experimental group. A repeated measures factorial analysis of variance (RM-ANOVA) was used in order to test within subject changes from the baseline to the follow-up, taking into account time and condition. Additionally, to take into account possible bias as a result of attrition, multilevel linear models were performed using measures of wellbeing, citizenship and their possible modificators as within-subject variables. Statistical analyses were conducted using SPSS version 22.

\section{Results}

\section{Sociodemographic characteristics and missing analysis}

All Kurtosis and Skewness parameters were within the -1.96 and 1.96 range recommended by Doane \& Seward (2011), thus we decided to use parametric statistics. We only found that 'Occupational wellbeing' and 'Care' had a Skewness and Kurtosis outside the range of -1 and +1 . 'World Stewardship' had a Skewness value below 1, whereas 'Economic wellbeing' and 'Aggressive assertiveness' had a Kurtosis value greater than 1. However, all the variables were within the -1.96 and 1.96 range. Sociodemographic characteristics and the ideology variables have been grouped and are shown in table 1 . There were no statistically significant differences between groups. The sample of randomised participants $74 \%$ females 
( $n=128$ ), represented 13 countries (including Australia, Bahrain, Belgium, Canada, China, France, Germany, Spain, Switzerland. The Netherlands, United Arab Emirates, The United Kingdom and United States of America). The participants were predominantly Caucasian $74.7 \%(n=130)$ with a small minority of participants representing other ethnicities such as Asian 10.9\% (n=19), Hispanic 2.9\% $(n=5)$, and African $4 \%(n=7)$. The majority of the respondents indicated that they were in employment $59.8 \%(n=104)$ had an undergraduate degree $50.6 \%$ $(n=88)$ and were currently in a relationship $67.8 \%(n=118)$. When we carried out the mean comparisons of baseline scores of participants completing the first follow-up with those who did not, we found statistically significant differences for the choice subscale of the citizenship questionnaire $(\mathrm{t}=1.976, \mathrm{p}=.05)$.

\section{Analysis of the relationship between wellbeing, citizenship and their modificators}

Table 2 shows that there were statistically significant positive correlations between all the citizenship and wellbeing subscales. In general the results suggest a positive relationship, with greater citizenship levels consequently leading to higher levels of wellbeing. The strongest correlation was found between 'Overall Life Wellbeing' and the citizenship subscales related to 'Personal Responsibility', 'Government and Infrastructure', 'Caring for others', 'Legal rights' and 'Choice'. We found a strong positive correlation between 'Civil Rights' and 'Economic Wellbeing' $(\mathrm{r}(182)=.54, \mathrm{p}=<.001)$. The citizenship subscale 'World Stewardship' indicates a statistically significant positive relationship with 'Psychological Wellbeing' ( $\mathrm{r}$ $(182)=.46, \mathrm{p}=<.001)$

Table 3 illustrates the relationship between the wellbeing and citizenship baseline totals and the modificator variables: 'Social Justice Beliefs', 'Assertiveness' and 'Values'. The correlation matrix confirms previous results as a positive relationship was found between the wellbeing and citizenship totals. There appears to be a statistically significant relationship 
between the wellbeing and citizenship baseline totals $(\mathrm{r}(182)=.62, \mathrm{p}<.001)$. However, there are no statistically significant correlations taking into account wellbeing and citizenship with the aforementioned variables. Within these variables, the matrix shows a low positive correlation between the 'Justice Value' subscale and the 'Aggressive Assertiveness' subscale $(\mathrm{r}(79)=.32, \mathrm{p}<.05)$

Table 4 demonstrates the relationship between the modificator variables and the wellbeing and citizenship subscales. Statistically significant correlations, always with low effect sizes, were found for the following variable diads:

- 'Beliefs in a just world' with 'Economic wellbeing' ( $\mathrm{r}=-.245, \mathrm{p}<.05$ ). 'Citizenship Government and Infrastructure' $(\mathrm{r}=-.216, \mathrm{p}<.05)$ and 'Citizenship Civil Rights' ( $\mathrm{r}=-$ $.214, \mathrm{p}<.05)$.

- 'Adaptive Assertiveness' with 'Occupational wellbeing' ( $r=.206, p<.05)$, and 'Psychological Wellbeing' (r=.282, p<.01) and 'Citizenship Personal Responsibility' $(\mathrm{r}=.229, \mathrm{p}<.05)$.

- 'Justice Values' with 'Citizenship Caring for others' ( $r=.228, \mathrm{p}<.05)$.

\section{Within groups prediction of group differences}

Table 5 shows within (paired samples t-test) and between (GLM, time by condition) group differences for wellbeing, citizenship and the modificator variables.

The results from the paired samples t-test indicate that no statistically significant differences were found for any of the wellbeing subscales. Regarding the citizenship variable, statistically significant differences were found for the subscale 'Personal Responsibility' (pre $M=3.94, S D=.51 ;$ post $M=4.03, S D=.56 ; t(52)=-2.07, p<.05, d=-0.28)$.

Statistically significant differences were also found for 'Beliefs in a Just World' (pre $M=3.96, S D=.96$; post $M=3.58, S D=.96 ; t(45)=3.25, p<.01, d=0.48)$. 


\section{Between groups prediction of group differences}

An independent samples t-test was conducted in order to compare wellbeing and citizenship levels between the control (within their intervention) and experimental (within their follow up) group. The results demonstrated that there were no statistically significant differences for wellbeing $t(51)=-0.88, p=.93$, and for citizenship levels $t(51)=-1.39, p=.17$. The findings from the modificators showed no statistically significant differences for 'Beliefs in a Just World' $t(51)=.872, p=.387$, 'Aggressive Assertiveness' $t(50)=1.38, p=.18$; 'Adaptive Assertiveness' $t(50)=-.70, p=.51, d=-0.01$; 'Justice' values $t(50)=-.41, p=.68$ and 'Care Values' $t(50)=-.96, p=.34$

\section{Time $\mathrm{x}$ Condition interaction in predicting within group differences}

The two-way factorial repeated measures analysis of variance (RM-ANOVA) shown in Table 5 found a statistically significant effect of time and condition on the citizenship subscale 'Legal Rights' $\left(\mathrm{F}(1,51)=5.72, p=.03, \eta p^{2}=.10\right)$.

The multilevel linear models showed no statistical significance for time by group interaction for any of the wellbeing, citizenship or modificator variables. However, when adding 'Care' to a model and using citizenship as the dependent variable, we found significance for time by 'Care' interaction $(\mathrm{F}(1,121.34)=6.7, \mathrm{p}=.01)$. This effect was found for all the citizenship subscales except for 'Caring for Others', which remained in a statistical tendency $(\mathrm{F}(1,99.384)=2.8, \mathrm{p}=.096)$. 
Table 1. Sociodemographic and baseline scores by group

\begin{tabular}{|c|c|c|c|c|c|c|}
\hline & \multicolumn{2}{|c|}{ Control } & \multicolumn{2}{|c|}{ Experimental } & \multicolumn{2}{|c|}{ Sstatistical significance } \\
\hline & $\mathrm{M}$ & SD & M & SD & $t$ & $\mathrm{p}$ \\
\hline Age (16-76) & 37.40 & 15.23 & 34.49 & 12.75 & 1.36 & .18 \\
\hline Ideology (range of 1-6) & 2.03 & 1.24 & 2.06 & 1.18 & -.14 & .89 \\
\hline \multirow[t]{2}{*}{ Beliefs in a Just World (range of 1-6) } & 4.10 & 1.54 & 4.11 & 1.53 & -.03 & .98 \\
\hline & $\mathrm{N}$ & $\%$ & $\mathrm{~N}$ & $\%$ & $\mathrm{OR}, 95 \% \mathrm{CI}$ & $\mathrm{p}$ \\
\hline Gender (females) & 68 & 76.4 & 60 & 71.4 & $.772, .391-1.525$ & .46 \\
\hline Race/ethnicity (white) & 68 & 75.6 & 62 & 73.8 & $1.097, .553-2.173$ & .79 \\
\hline Education (Attended High School/College) & 17 & 22.4 & 17 & 21.5 & $1.051, .491-2.249$ & .90 \\
\hline Country of Residence (United Kindgdom) & 57 & 79.2 & 56 & 78.9 & $1.018, .455-2.277$ & .97 \\
\hline Country of Origin (United Kingdom) & 51 & 67.1 & 54 & 76.1 & $.642, .311-1.326$ & .23 \\
\hline Relationship status (married or in a relationship) & 60 & 66.7 & 58 & 69.0 & $.897, .474-1.696$ & .74 \\
\hline Occupation (working or studying) & 53 & 58.9 & 51 & 60.7 & $.927, .505-1.700$ & .81 \\
\hline Social status (middle class or above) & 55 & 61.1 & 57 & 67.9 & $.744, .399-1.389$ & .35 \\
\hline
\end{tabular}

*A small sample of participants experienced technical failures which led to the inability of completing the baseline 
Table 2: Correlation matrix for all subscales of wellbeing and citizenship

\begin{tabular}{|c|c|c|c|c|c|c|c|c|c|c|c|c|c|c|}
\hline Variables & 1 & 2 & 3 & 4 & 5 & 6 & 7 & 8 & 9 & 10 & 11 & 12 & 13 & 14 \\
\hline \multicolumn{15}{|l|}{ I-Coppe } \\
\hline 1.Overall Life wellbeing & 1 & & & & & & & & & & & & & \\
\hline 2.Interpersonal wellbeing & $.658 * * *$ & 1 & & & & & & & & & & & & \\
\hline 3. Community wellbeing & $.534 * * *$ & $.459 * * *$ & 1 & & & & & & & & & & & \\
\hline 4. Occupational wellbeing & $.695 * * *$ & $.499 * * *$ & $.505 * * *$ & 1 & & & & & & & & & & \\
\hline 5. Physical wellbeing & $.676 * * *$ & $.542 * * *$ & $.477 * * *$ & $.512 * * *$ & 1 & & & & & & & & & \\
\hline 6. Psychological wellbeing & $.774 * * *$ & $.630 * * *$ & $.393 * * *$ & $.603 * * *$ & $.680 * * *$ & 1 & & & & & & & & \\
\hline 7. Economic wellbeing & $.681 * * *$ & $.442 * * *$ & $.461 * * *$ & $.640 * * *$ & $.537 * * *$ & $.581 * * *$ & 1 & & & & & & & \\
\hline 8. Personal responsibility & $.573 * * *$ & $.472 * * *$ & $.390 * * *$ & $.430 * * *$ & $.423 * * *$ & $.566^{* * * *}$ & $.468 * * *$ & 1 & & & & & & \\
\hline $\begin{array}{l}\text { 9. Government \& } \\
\text { Infrastructure }\end{array}$ & $.497 * * *$ & $.317 * * *$ & $.296 * * *$ & $.417 * * *$ & $.328 * * *$ & $.386^{* * *}$ & $.475 * * *$ & $.674 * * *$ & 1 & & & & & \\
\hline 10. Caring for others & $.452 * * *$ & $.423 * * *$ & $.374 * * *$ & $.325^{* * *}$ & $.323 * * *$ & $.407 * * *$ & $.328 * * *$ & $.689 * * *$ & $.579 * * *$ & 1 & & & & \\
\hline 11. Civil Rights & $.502 * * *$ & $.400 * * *$ & $.370 * * *$ & $.417 * * *$ & $.400 * * *$ & $.415^{* * *}$ & $.537 * * *$ & $.686^{* * *}$ & $.751 * * *$ & $.537 * * *$ & 1 & & & \\
\hline 12. Legal Rights & $.387 * * *$ & $.288 * * *$ & $.221 * *$ & $.300 * * *$ & $.326 * * *$ & $.343^{* * *}$ & $.353 * * *$ & $.608 * * *$ & $.671^{* * *}$ & $.500 * * *$ & $.696^{* * *}$ & 1 & & \\
\hline 13. Choice & $.512 * * *$ & $.414 * * *$ & $.312 * * *$ & $.364 * * *$ & $.453 * * *$ & $.467 * * *$ & $.443 * * *$ & $.734 * * *$ & $.681 * * *$ & $.562 * * *$ & $.711 * * *$ & $.720 * * *$ & 1 & \\
\hline 14. World Stewardship & $.438 * * *$ & $.362 * * *$ & $.416^{* * *}$ & $.334 * * *$ & $.359 * * *$ & $.462 * * *$ & $.304 * * *$ & $.709^{* * *}$ & $.480^{* * *}$ & $.630 * * *$ & $.491^{* * *}$ & $.461 * * *$ & $.428 * * *$ & 1 \\
\hline
\end{tabular}

*(1) Overall wellbeing; (2) Interpersonal wellbeing; (3) Community wellbeing; (4) Occupational wellbeing; (5) Physical wellbeing; (6) Psychological wellbeing; (7) Economic wellbeing; (8) Personal responsibility; (9) Government Infrastructure; (10) Caring for others; (11) Civil Rights; (12) Legal Rights; (13) Choice; (14) World Stewardship

$* * \mathrm{p}<0.01 . * * * \mathrm{p}<0.001$ 
Table 3: Correlation matrix including modificators at baseline

\begin{tabular}{|c|c|c|c|c|c|c|c|}
\hline Variables & 1 & 2 & 3 & 4 & 5 & 6 & 7 \\
\hline 1.Wellbeing & 1 & & & & & & \\
\hline 2. Citizenship & $.624 * * *$ & 1 & & & & & \\
\hline 3. Beliefs in a just world & -.099 & -.151 & 1 & & & & \\
\hline 4.Aggressive assertiveness & -.036 & .001 & -.048 & 1 & & & \\
\hline 5.Adaptive assertiveness & .201 & .168 & .157 & $.426 * * *$ & 1 & & \\
\hline 6. Justice Value & .206 & .050 & .034 & $.320 * *$ & .095 & 1 & \\
\hline 7. Care Value & .091 & -.080 & -.072 & .092 & .049 & $.472 * * *$ & 1 \\
\hline
\end{tabular}

*(1) Wellbeing; (2) Citizenship; (3) Beliefs in a just world; (4) Aggressive assertiveness; (5) Adaptive assertiveness; (6) Justice Value; (7) Care Value.

${ }^{*} \mathrm{p}<.01 .{ }^{*} * \mathrm{p}<0.01 .{ }^{* * *} \mathrm{p}<0.001$ 
Table 4: Correlation matrix of the subscales and the modificators

\begin{tabular}{|c|c|c|c|c|c|c|c|c|c|c|c|c|}
\hline & 1 & 2 & 3 & 4 & 5 & 6 & 7 & 8 & 9 & 10 & 11 & 12 \\
\hline 1.Economic Wellbeing & 1 & & & & & & & & & & & \\
\hline 2.Occupational Wellbeing & $.640 * *$ & 1 & & & & & & & & & & \\
\hline 3.Psychological Wellbeing & $.581 * *$ & $.603 * *$ & 1 & & & & & & & & & \\
\hline 4.Personal Responsibility & $.468 * *$ & $.430 * *$ & $.566^{* *}$ & 1 & & & & & & & & \\
\hline 5.Government \& Infrastructure & $.475 * *$ & $.417 * *$ & $.386^{* *}$ & $.674 * *$ & 1 & & & & & & & \\
\hline 6.Caring for others & $.328 * *$ & $.325 * *$ & $.407 * *$ & $.689 * *$ & $.579 * *$ & 1 & & & & & & \\
\hline 7.Civil Rights & $.537 * *$ & $.417 * *$ & $.415^{* *}$ & $.686 * *$ & $.751 * *$ & $.537 * *$ & 1 & & & & & \\
\hline $\begin{array}{l}\text { 8. Beliefs in a just world baseline } \\
\text { total' }\end{array}$ & $-.245^{*}$ & -.160 & .013 & -.100 & $-.216^{*}$ & -.038 & $-.214^{*}$ & 1 & & & & \\
\hline $\begin{array}{l}\text { 9.Aggressive assertiveness } \\
\text { baseline total }\end{array}$ & -.027 & -.007 & .018 & .020 & .046 & .105 & -.055 & -.048 & 1 & & & \\
\hline $\begin{array}{l}\text { 10. Adaptive assertiveness } \\
\text { baseline total }\end{array}$ & .072 & $.206^{*}$ & $.282 * *$ & $.229 *$ & .127 & .164 & .054 & .157 & $.426 * *$ & 1 & & \\
\hline 11.Justice baseline total' & .184 & .159 & .173 & .060 & .038 & $.228 *$ & -.062 & .034 & $.320 * *$ & .095 & 1 & \\
\hline 12. Care baseline total' & .085 & .119 & -.046 & -.021 & -.136 & .005 & -.106 & -.072 & .092 & .049 & $.472 * *$ & 1 \\
\hline
\end{tabular}

world baseline total; (9) Aggressive assertiveness baseline total; (10) Adaptive assertiveness baseline total; (11) Justice baseline total; (12) Care baseline total 
Table 5: Baseline and follow-up scores for wellbeing, citizenship and the modificators

\begin{tabular}{|c|c|c|c|c|c|c|c|c|c|c|c|c|c|c|c|c|c|c|c|}
\hline \multirow{3}{*}{ Outcomes } & \multicolumn{6}{|c|}{ Baseline } & \multicolumn{10}{|c|}{ Post intervention } & & & \\
\hline & \multicolumn{2}{|c|}{$\begin{array}{l}\text { Control } \\
(n=33)\end{array}$} & \multicolumn{2}{|c|}{$\begin{array}{l}\text { Experimental } \\
(n=28)\end{array}$} & \multicolumn{2}{|l|}{ Total } & \multicolumn{2}{|c|}{$\begin{array}{l}\text { Control } \\
(n=33)\end{array}$} & \multicolumn{2}{|c|}{ Experimental } & \multicolumn{2}{|l|}{ Total } & \multicolumn{4}{|c|}{ GLM (time by condition)* } & \multicolumn{3}{|c|}{ Paired sample t-test** } \\
\hline & $M$ & $\mathrm{SD}$ & $M$ & SD & $M$ & SD & $\mathrm{M}$ & SD & $\mathrm{M}$ & SD & $\mathrm{M}$ & SD & $\mathrm{F}$ & $p$ & $\eta p^{2}$ & Power & $\mathrm{t}$ & $p$ & $d$ \\
\hline Overall Life Wellbeing & 6.86 & 1.55 & 6.73 & 1.73 & 6.80 & 1.62 & 7.14 & 1.41 & 6.90 & 1.51 & 7.03 & 1.45 & .23 & .63 & .004 & .08 & -1.70 & .10 & -.23 \\
\hline Interpersonal Wellbeing & 7.87 & 1.43 & 7.52 & 1.88 & 7.71 & 1.64 & 7.78 & 1.61 & 7.52 & 1.67 & 7.66 & 1.63 & .77 & .78 & .001 & .06 & 1.59 & .12 & .22 \\
\hline Community Wellbeing & 6.21 & 1.87 & 6.27 & 1.66 & 6.24 & 1.76 & 6.55 & 1.93 & 6.12 & 2.13 & 6.35 & 2.02 & 1.33 & .25 & .022 & .21 & -.06 & .95 & -.01 \\
\hline Occupational Wellbeing & 6.89 & 2.08 & 6.83 & 1.99 & 6.86 & 2.02 & 6.85 & 2.01 & 6.95 & 1.94 & 6.90 & 1.96 & .21 & .65 & .004 & .07 & -.80 & .43 & .11 \\
\hline Physical Wellbeing & 7.16 & 1.45 & 6.86 & 2.08 & 7.02 & 1.76 & 7.22 & 1.61 & 6.99 & 1.81 & 7.11 & 1.69 & .04 & .84 & .001 & .05 & -.14 & .89 & -.02 \\
\hline Psychological Wellbeing & 7.13 & 1.77 & 7.08 & 1.70 & 7.11 & 1.72 & 7.41 & 1.70 & 6.92 & 1.91 & 7.19 & 1.80 & 2.64 & .11 & .043 & .36 & -.18 & .86 & -.03 \\
\hline Economic Wellbeing & 6.68 & 2.03 & 6.73 & 1.89 & 6.70 & 1.95 & 6.80 & 1.68 & 6.77 & 1.92 & 6.79 & 1.78 & .06 & .81 & .001 & .06 & .13 & .90 & .02 \\
\hline Wellbeing total & 6.97 & 1.31 & 6.86 & 1.42 & 6.92 & 1.35 & 7.11 & 1.42 & 6.88 & 1.46 & 7.00 & 1.43 & .41 & .52 & .007 & .10 & -.23 & .82 & -.03 \\
\hline Personal responsibility & 3.94 & 0.55 & 3.95 & 0.53 & 3.95 & 0.54 & 4.03 & 0.57 & 4.06 & 0.63 & 4.04 & 0.59 & .03 & .87 & .000 & .05 & -2.07 & $<.05$ & -.28 \\
\hline Government \& Infrastructure & 3.88 & 0.73 & 3.79 & 0.61 & 3.84 & 0.68 & 3.91 & 0.75 & 3.93 & 0.70 & 3.92 & 0.72 & .85 & .36 & .014 & .15 & -.86 & .39 & -.12 \\
\hline Caring for others & 3.89 & 0.67 & 3.99 & 0.75 & 3.94 & 0.70 & 3.96 & 0.72 & 4.08 & 0.77 & 4.02 & 0.74 & .04 & .85 & .001 & .05 & -.66 & .51 & -.09 \\
\hline Civil Rights & 4.02 & 0.67 & 3.87 & 0.62 & 3.95 & 0.64 & 4.10 & 0.57 & 4.04 & 0.69 & 4.07 & 0.62 & .53 & .47 & .009 & .11 & -1.73 & .09 & -.24 \\
\hline Legal Rights & 4.25 & 0.47 & 4.22 & 0.57 & 4.24 & 0.51 & 4.19 & 0.50 & 4.39 & 0.52 & 4.28 & 0.52 & 4.88 & .03 & .076 & .59 & -.73 & .47 & -.10 \\
\hline Choice & 4.45 & 0.43 & 4.35 & 0.47 & 4.40 & 0.44 & 4.46 & 0.51 & 4.44 & 0.45 & 4.45 & 0.48 & .90 & .35 & .015 & .16 & .04 & .97 & .006 \\
\hline World Stewardship & 3.55 & 0.79 & 3.49 & 0.85 & 3.52 & 0.82 & 3.68 & 0.70 & 3.65 & 0.88 & 3.67 & 0.78 & .48 & .83 & .001 & .06 & -1.02 & .31 & -.14 \\
\hline Citizenship total & 4.04 & 0.48 & 3.99 & 0.50 & 4.01 & 0.49 & 4.09 & 0.51 & 4.11 & 0.53 & 4.10 & 0.52 & 1.19 & .28 & .020 & .19 & -1.51 & .14 & -.21 \\
\hline Beliefs in a just world & 4.02 & 0.81 & 3.79 & 1.08 & 3.91 & 0.95 & 3.91 & 0.83 & 3.51 & 1.05 & 3.72 & 0.96 & 1.11 & .30 & .020 & .18 & 3.25 & $<<.01$ & .48 \\
\hline
\end{tabular}




\begin{tabular}{|c|c|c|c|c|c|c|c|c|c|c|c|c|c|c|c|c|c|c|c|}
\hline Aggressive assertiveness & 2.15 & 0.46 & 1.98 & 0.64 & 2.07 & 0.56 & 2.15 & 0.46 & 1.94 & 0.60 & 2.05 & 0.54 & .40 & .53 & .008 & .10 & .43 & .67 & .06 \\
\hline Adaptive assertiveness & 3.70 & 0.58 & 3.46 & 0.63 & 3.59 & 0.61 & 3.63 & 0.62 & 3.58 & 0.58 & 3.61 & 0.60 & 2.51 & .12 & .046 & .34 & .06 & .95 & .009 \\
\hline Justice values & 6.49 & 1.62 & 6.40 & 1.72 & 6.45 & 1.65 & 6.42 & 1.63 & 6.54 & 1.17 & 6.48 & 1.40 & .51 & .48 & .010 & .11 & -.89 & .38 & -.13 \\
\hline Care values & 7.68 & 1.28 & 7.65 & 1.36 & 7.67 & 1.31 & 7.52 & 1.37 & 7.69 & 1.17 & 7.61 & 1.26 & 3.73 & .54 & .008 & .09 & 1.06 & .30 & 0.16 \\
\hline
\end{tabular}

* For these calculations we included the control group before they completed the intervention (second measurement) and compared this with the follow-up of the experimental group. ** These calculations were performed comparing baseline with follow up (after having participated in the intervention) for both groups. 


\section{Discussion}

The present study investigated the relationship between wellbeing, citizenship and the variables that may modify this relationship 'Social Justice Beliefs', 'Assertiveness' and 'Values'. For instance individuals who have high levels of beliefs in a just world and a low adaptive assertive style are less likely to fight for their citizenship rights and the rights of others, and will be less concerned with promoting well-being (Ames et al., 2017; Ames \& Flynn, 2007; Dalbert, 2001; Lange \& Jakubowski, 1978; Lipkusa et al., 1996; Stroebe, 2013; Thompson \& Berenbaum, 2011).

The study also tested the stability of the wellbeing and citizenship measures over time after taking part in a short experiment. This was related to the modificators with the view that after completing the questionnaires and visualising the videos related to active citizenship and community engagement, 'Social Justice Beliefs', 'Assertiveness' and 'Values', participant's overall wellbeing and sense of citizenship would change.

The findings supported the first hypothesis as a strong positive relationship was found between wellbeing and citizenship (H1a). These results reiterate previous research which found that subjective wellbeing was positively linked to citizenship dimensions (Zalewska \& Zawadzka, 2016). As previously found 'giving back' to the community and being a valued citizen, such as being involved in volunteering, led to increases in overall quality of life and has been linked to a number of health benefits (Clayton et al., 2013; Hunter \& Linn, 1981).

Despite the strong relationship between wellbeing and citizenship, the second part of the first hypothesis was only partially met (H1b). This is because a statistically significant relationship was not found between all the wellbeing and citizenship subscales when taking into account the variables; 'Social Justice Beliefs', 'Assertiveness' and 'Values'. The results indicated a negative relationship between 'Economic Wellbeing' and 'Beliefs in a Just World'. 
Research has suggested that after exposure to inequality this threatens 'Economic Wellbeing' with an increased acknowledgement of income inequality in society (Furnham \& Gunter, 1984; Jost, Blount, Pfeffer, \& Hunyady, 2003). In the case of our study, the video which illustrated priviledged and underpriviledged individuals may have led to a greater awareness of inequality, which is still apparent between lower and higher social class groups. A negative relationship has also been attributed between 'Economic Wellbeing', 'Social Justice' and political beliefs. This is because previous research has shown that left-wing individuals believe that there is a negative relationship between economic performance and escaping from poverty. This could in part explain the results of the current research as a high percentage of participants $(89.7 \%)$ could be considered as having 'left-wing' views.

Additionally, in line with our findings, a negative correlation was found between the citizenship subscale 'Government \& Infrastructure' and 'Beliefs in a Just World'. This may be linked to previous research indicating that left-wing individuals tend to believe that the government is doing too little to help the poor (Di Tella \& MacCulloch, 2014). This view is further divided among countries, with $69.7 \%$ of Europeans, which made up $83.2 \%$ of our sample, reporting that they are receiving too little help from the government. Alesina \& Angeletos (2002) reported that $60 \%$ of Americans - yet only $26 \%$ of Europeans- believe the poor are lazy. It has been argued that the countries where few people hold this belief also have more government intervention, this indicates that aid from the government does not necessarily influence the perception of a just world.

A positive relationship was found between 'Adaptive Assertiveness' and 'Occupational Wellbeing' which reiterates previous findings which have implemented assertiveness programmes. Occupational therapists have administered 'Assertive Community Treatment' (ACT) in order to assist vulnerable individuals so that they have the capacity to experience rich 
occupational lives which is essential to overall health and well-being (Krupa, Radloff-Gabriel, Whippey, \& Kirsh, 2002). 'Adaptive Assertiveness' was also correlated to 'Psychological Wellbeing' which has previously been linked to lower levels of anxiety and depression, as well as improvements in life satisfaction and self-esteem (Ahmadi et al., 2017; Chan, 1993; Rathus, 1972). 'Adaptive Assertiveness' has previously been found to be strongly correlated to the citizenship subscale 'Personal Responsibility', which was also the case in the current study. Previous research has found that assertive citizens are more engaged in wider society due to discussing and negotiating the kinds of benefits they wish to receive from public services. For example, parents who take an active interest in their child's education are more likely to see them perform better at school. Similartly, patients who are informed and willing to take a role in securing their own health tend to recover more quickly and stay healthier for longer. Under this view, service users and providers share the responsibility for outcomes which helps to shift power and responsibility towards the citizen (Griffiths et al., 2009).

'Justice' values were positively correlated to the citizenship subscale 'Caring for others'. Previous work has found a close link between 'Justice values' and 'Care' with the belief that they work together in achieving social change. For instance justice has been linked to ensuring that individuals are provided for by distributing the necessary resources in society, but more importantly that they are allocated equally (Nelson et al., 1998; Prilleltensky \& Nelson, 1997). The concept of equal allocation is governed by care and compassion which is administered in the form of physical and psychological concern for others in the community (Nelson et al., 2001; Swanson, 2010).

The within group hypothesis was partly supported as although no statistically significant alterations were found in overall wellbeing, some statistically significant changes were found in the citizenship subscales (H2). Changes were seen, after completing the short experiment, 
for the citizenship subscale 'Personal Responsibility' and 'Beliefs in a Just World' (H2a) The variable 'Personal Responsibility' has previously been seen as a moderator for the effects of just-world beliefs. More specifically when evidence provides the opportunity to blame the victim, individuals who score high in just world beliefs are more likely to seize this opportunity. Whereas, in other cases where the individual could not do anything to avoid their fate, high just world perceivers actually demonstrate greater sympathy towards the victim (Braman \& Lambert, 2001). In this experiment we saw higher rates of 'Personal Responsibility' at the follow-up but lower rates of 'Beliefs in a Just World'. This may suggest that individuals felt more responsible for their own actions and for the wellbeing of others, but due to the lower levels of beliefs in a just world they did not appear to attribute the blame to the individual presented in the video.

The between groups hypothesis was not supported as there were no statistically significant differences between groups $(\mathrm{H} 2 \mathrm{~b})$. The experimental group did not show statistically significant differences at follow-up to the control group. This may suggest that condition was not a statistically significant contributor in achieving changes in overall wellbeing and sense of citizenship.

The last hypothesis was partly supported as there was a statistically significant effect for the Citizenship subscale 'Legal Rights' (H2c). Research has proposed that a person who is aware that he possesses rights will utilise the legal system as a resource and a means of validating his rights (Lister, 2004), whereas a lack of support for legal rights perpetuates and maintains inequality (Watts, 2017).

Additionally, a statistically significant interaction was found between 'Care' and time for the citizenship subscales. This is not surprising due to the close link that has been found between 'Care Values' and 'Legal Rights'. Past research has found a relationship between the 
existing laws and policies and the diminishing value of care (McClain, 2000). This is because much of the common law is based on the assumption that we are independent from others and therefore are entitled to have our rights of self determination and autonomy fiercely protected (Lloyd, 2004).

Despite seeing increases in the citizenship subscales after taking part in the short experiment, there were no statistically significant differences for the wellbeing measures. These results could be due to the nature of this study which in turn influenced outcomes. For example this was a web-based experiment which measured participants longitudinally after only a one or two week gap. Studies have indicated improvements in 'Interpersonal', 'Community', 'Psychological' and 'Economic' wellbeing after 30 and 60 days post-baseline. For wellbeing subscales related to 'Physical', 'Emotional' and 'Overall Life' even greater time is needed in order to see improvements. Therefore, it may be the case that more time was needed between the baseline and follow-up in order to see statistically significant changes in the different wellbeing subscales (Myers et al., 2017).

Limitations of the current study should be noted, firstly due to the voluntary nature of the experiment there was a high attrition rate. The study's advertisement on social media initially attracted 242 participants who followed the link and enrolled in the study. However, this reduced to 182 as not all of the participants finished the wellbeing and citizenship measures, indicating an initial attrition rate of $24.79 \%$. This reduction in numbers may have been due to it being an online voluntary study, the length of each section and even participant variables such as not having the time to complete the follow-ups. Additionally, it is also important to take into account that due to the nature and structure of the study (i.e. it was a questionnaire-based study and that a wellbeing and citizenship score was provided at each stage) this may have led to more favourable responses by the participants. Therefore, it may not be the case that the 
responses were completely representative of the respondent's subjective wellbeing and citizenship levels.

A further limitation was that this was an exploratory study and therefore its results should be replicated in larger trials in order to establish more clearly the link between the variables tested in the current experiment. Lastly, the participants were predominantly representative of white well-educated females from the United Kingdom. However, the study achieved a range of participants worldwide from 13 different countries ranging from 16 to 76 years of age.

\section{Practical implications.}

The findings from the brief experiment have helped to contextualise citizenship in the context of wellbeing. The concern for individuals in their social context and for promoting wellness in communities creates a space to understand and support other members of the community in becoming a full citizen (Ponce \& Rowe, 2018). This is based on the premise that communities and society as a whole have an obligation to support the citizenship of marginalised groups by supporting their access to the five R's; Rights, Responsibilities, Roles, Resources and Relationships (Ponce \& Rowe, 2018). The current experiment can help to change the way in which individuals in the general public consider the concept of citizenship, moving away from it being the 'person's responsibility' to one that places the responsibility on society as a whole (Rowe \& Davidson, 2016). We aimed to change views by educating the public about the needs of marginalised groups and the contributions they can make in their home communities.

In conclusion, the brief experiment has provided an insight into the complexity and the multitude of factors that contribute to both wellbeing and citizenship. As we have seen from the results, the variables have been influential in changing some of the citizenship subscales 
and may have the potential to contribute to wellbeing. This is encouraging as it has enabled us to understand that these variables, when studied over a longer period of time and applied to real life settings, could give us a better indication of the interplay between wellbeing and citizenship.

\section{Publisher's Note}

Springer Nature remains neutral with regard to jurisdictional claims in published maps and institutional affiliations.

\section{Funding}

This project has received funding from the European Union's Framework Programme for Research and Innovation Horizon 2020 (2014-2020) under the Marie Sklodowska-Curie Grant Agreement No 654808.

\section{References}

Ahmadi, H., Daramadi, P. S., Asadi-Samani, M., Givtaj, H., \& Sani, M. R. M. (2017). Effectiveness of Group Training of Assertiveness on Social Anxiety among Deaf and Hard of Hearing Adolescents. The International Tinnitus Journal, 21(1), 14-20. https://doi.org/10.5935/0946-5448.20170004

Alberti, R., \& Emmons, M. (1995). Your perfect right: A guide to assertive living . San Luis Obispo. CA: impact.

Alesina, A., \& Angeletos, M. (2002). Fairness and redistribution: US versus Europe. Cambridge, Massachusetts: Harvard Institute of Economic Research, Harvard University. Allport, G. W. (1954). The nature of prejudice. New York: Addison.

Ambrosio, A. L., \& Sheehan, E. P. (1990). Factor Analysis of the Just World Scale. The Journal of Social Psychology, 130(3), 413-415. https://doi.org/10.1080/00224545.1990.9924600

Ames, D. R., \& Flynn, F. J. (2007). What breaks a leader: the curvilinear relation between assertiveness and leadership. Journal of Personality and Social Psychology, 92(2), 307- 
324. https://doi.org/10.1037/0022-3514.92.2.307

Ames, D. R., Lee, A., \& Wazlawek, A. (2017). Interpersonal assertiveness: Inside the balancing act. Social and Personality Psychology Compass, 11(6). https://doi.org/10.1111/spc3.12317

Aubé, J. (2007). Balancing Concern for Other With Concern for Self: Links Between Unmitigated Communion, Communion, and Psychological Well-Being. Journal of Personality, 76(1), 101-134. https://doi.org/10.1111/j.1467-6494.2007.00481.x

Bemak, F., \& Chung, R. C.-Y. (2005). Advocacy as a Critical Role for Urban School Counselors: Working Toward Equity and Social Justice. Professional School Counseling, 8(3), 196-202. https://doi.org/10.2307/42732459

Bouvard, M., Arrindell, W. A., Guérin, J., Bouchard, C., Rion, A. C., Ducottet, E., ... Cottraux, J. (1999). Psychometric appraisal of the scale for interpersonal behavior (SIB) in France. Behaviour Research and Therapy, 37(8), 741-762. https://doi.org/10.1016/S00057967(98)00187-9

Braman, A. C., \& Lambert, A. J. (2001). Punishing Individuals for Their Infirmities: Effects of Personal Responsibility, Just-World Beliefs, and In-Group/Out-Group Status. Journal of Applied Social Psychology, 31(5), 1096-1109. https://doi.org/10.1111/j.15591816.2001.tb02664.x

Cameron, G., Peirson, L., \& Pancer, S. (2009). Resident Participation in the Better Beginnings, Better Futures Prevention Project: Part II-Factors That Facilitate and Hinder Involvement. Canadian Journal of Community Mental Health, 13(2), 213-227. https://doi.org/https://doi.org/10.7870/cjcmh-1994-0022

Cantril, H. (1965). Pattern of human concerns. New Brunswick: Rutgers University Press.

Caputi, P. (1994). Factor Structure of the Just World Scale Among Australian Undergraduates. 
The Journal of Social Psychology, 134(4), 475-482. https://doi.org/10.1080/00224545.1994.9712198

Chan, D. W. (1993). Components of assertiveness: Their relationships with assertive rights and depressed mood among Chinese college students in Hong Kong. Behaviour Research and Therapy, 31(5), 529-538. https://doi.org/10.1016/0005-7967(93)90135-H

Chan, K., \& Chiu, M. (2007). The Politics of Citizenship Formation: Political Participation of Mental Health Service Users in Hong Kong. Asian Journal of Social Science, 35(2), 195215. https://doi.org/10.1163/156853107X203432

Church, K. (1995). Forbidden narratives: Critical autobiography as social science (Vol. 2). Amsterdam: Gordon and Breach Publishers.

Clayton, A., O’Connell, M. J., Bellamy, C., Benedict, P., \& Rowe, M. (2013). The Citizenship Project part II: impact of a citizenship intervention on clinical and community outcomes for persons with mental illness and criminal justice involvement. American Journal of Community Psychology, 51(1-2), 114-122. https://doi.org/10.1007/s10464-012-9549-z

Couch, J. V. (1998). Another Psychometric Evaluation of the Just World Scale. Psychological Reports, 82(3_suppl), 1283-1286. https://doi.org/10.2466/pr0.1998.82.3c.1283

Dalbert, C. (2000). Beliefs in a just world questionnaire. In J. Maltby, C. A. Lewis, \& A. Hill (Eds.), Commissioned reviews of 250 psychological tests (pp. 461-465). Lampeter, UK: Edwin Mellen Press.

Dalbert, C. (2001). The Justice Motive as a Personal Resource: Dealing with Challenges and Critical Life Events. New York, NY: Kluwer Academic/Plenum Publishers.

Di Tella, R., \& MacCulloch, R. (2014). Culture, Beliefs and Economic Performance (No. 1406).

Dittmar, H., \& Dickinson, J. (1993). The perceived relationship between the belief in a just 
world and sociopolitical ideology. Social Justice Research, 6(3), 257-272. https://doi.org/10.1007/BF01054461

Doane, D. P., \& Seward, L. E. (2011). Measuring Skewness: A Forgotten Statistic? Journal of Statistics Education, 19(2). https://doi.org/10.1080/10691898.2011.11889611

Dolan, P. (2010). Youth civic engagement and support: Promoting well-being with the assistance of a UNESCO agenda. In C.McAuley \& W. Rose (Ed.), Child well-being; Understanding children's lives (pp. 111-126). London, England: Jessica Kingsley.

Flanagan, C., \& Levine, P. (2010). Civic Engagement and the Transition to Adulthood. The Future of Children, 20(1), 159-179. https://doi.org/10.1353/foc.0.0043

Fondacaro, M. R., \& Weinberg, D. (2002). Concepts of Social Justice in Community Psychology: Toward a Social Ecological Epistemology. American Journal of Community Psychology, 30(4), 473-492. https://doi.org/10.1023/A:1015803817117

Furnham, A. (2003). Belief in a just world: research progress over the past decade. Personality and Individual $\quad$ Differences, $\quad 34(5), \quad 795-817$. https://doi.org/https://doi.org/10.1016/S0191-8869(02)00072-7

Furnham, A., \& Gunter, B. (1984). Just world beliefs and attitudes towards the poor. British Journal of Social Psychology, 23(3), 265-269. https://doi.org/10.1111/j.20448309.1984.tb00637.x

Fyfe, N. R., \& Milligan, C. (2003). Space, Citizenship, and Voluntarism: Critical Reflections on the Voluntary Welfare Sector in Glasgow. Environment and Planning A, 35(11), 20692086. https://doi.org/10.1068/a35306

Gilster, M. E. (2012). COMPARING NEIGHBORHOOD-FOCUSED ACTIVISM AND VOLUNTEERISM: PSYCHOLOGICAL WELL-BEING AND SOCIAL CONNECTEDNESS. Journal of Community Psychology, 40(7), 769-784. 
https://doi.org/10.1002/jcop.20528

Ginwright, S., \& James, T. (2002). From assets to agents of change: Social justice, organizing, and youth development. New Directions for Student Leadership, 2002(96), 27-46. https://doi.org/10.1002/yd.25

Griffiths, S., Foley, B., \& Prendergrast, J. (2009). Assertive Citizens New Relationships in the Public Services. London: Social Market Foundation.

Gump, L. S., Baker, R. C., \& Roll, S. (2000). The moral justification scale: Reliability and validity of a new measure of care and justice orientations. Adolescence, 35(137), 67-76.

Habib, S. (2011). Applications Of Moral Justification Scale To Investigate Justice And Care Orientations Among University Students. Foundation University.

Haste, H. (2004). Constructing the citizen. Political Psychology, 25(3), 413-439. https://doi.org/10.1111/j.1467-9221.2004.00378.x

Hunter, K. I., \& Linn, M. W. (1981). Psychosocial Differences between Elderly Volunteers and Non-Volunteers. The International Journal of Aging and Human Development, 12(3), 205-213. https://doi.org/10.2190/0H6V-QPPP-7JK4-LR38

Inglehart, R., Basanez, M., \& Diez-Medrano, J. (2000). World values surveys and European values surveys, 1981-1984, 1990-1993, and 1995-1997. Ann Arbor-Michigan.

Janoski, T. (1998). Citizenship and Civil Society : a Framework of Rights and Obligations in Liberal, Traditional, and social democratic regimes. Cambridge University Press.

Jiang, F., Yue, X., Lu, S., Yu, G., \& Zhu, F. (2016). How Belief in a Just World Benefits Mental Health: The Effects of Optimism and Gratitude. Social Indicators Research, 126(1), 411423. https://doi.org/10.1007/s11205-015-0877-x

Jost, J. T., Blount, S., Pfeffer, J., \& Hunyady, G. (2003). FAIR MARKET IDEOLOGY: ITS COGNITIVE-MOTIVATIONAL UNDERPINNINGS. Research in Organizational 
Behavior, 25, 53-91. https://doi.org/10.1016/S0191-3085(03)25002-4

Kekes, J. (1993). The Morality of Pluralism. Princeton, NJ: Princeton University Press.

Kendrick Jr, J. R. (1996). Outcomes of service-learning in an introduction to sociology course. Michigan Journal of Community Service Learning, 3, 72-81.

Kiselica, M. S., \& Robinson, M. (2001). Bringing Advocacy Counseling to Life: The History, Issues, and Human Dramas of Social Justice Work in Counseling. Journal of Counseling \& Development, 79(4), 387-397. https://doi.org/10.1002/j.1556-6676.2001.tb01985.x

Krupa, T., Radloff-Gabriel, D., Whippey, E., \& Kirsh, B. (2002). Reflections On... Occupational Therapy and Assertive Community Treatment. Canadian Journal of Occupational Therapy, 69(3), 153-157. https://doi.org/10.1177/000841740206900305

Lange, A., \& Jakubowski, P. (1978). The Assertive Option: Your Rights and Responsibilities. Champaign, Illinois: Research Press Co.

Lipkusa, I. M., Dalbert, C., \& Siegler, I. C. (1996). The Importance of Distinguishing the Belief in a Just World for Self Versus for Others: Implications for Psychological Well-Being. Personality and Social Psychology Bulletin, 22(7), 666-677. https://doi.org/10.1177/0146167296227002

Lister, R. (2004). Poverty. Cambridge, UK: Polity Press.

Lloyd, L. (2004). Mortality and morality: ageing and the ethics of care. Ageing and Society, 24(02), 235-256. https://doi.org/10.1017/S0144686X03001648

McClain, L. C. (2000). Care as a Public Value: Linking Responsibility, Resources, and Republicanism. Chicago-Kent Law Review, 76(3).

Mohr, P. B., \& Luscri, G. (1995). Social Work Orientation and Just World Beliefs. The Journal of Social Psychology, 135(1), 101-103. https://doi.org/10.1080/00224545.1995.9711408 Montague, A. C., \& Eiroa-Orosa, F. J. (2017). Exploring the Role of Engagement on Well- 
Being and Personal Development: A Review of Adolescent and Mental Health Activism. In N. J. L. Brown, T. Lomas, \& F. J. Eiroa-Orosa (Eds.), The Routledge International Handbook of Critical Positive Psychology. London, UK: Routledge.

Montague, A. C., \& Eiroa-Orosa, F. J. (2018). In it together: Exploring how belonging to a youth activist group enhances well-being. Journal of Community Psychology, 46(1), 2343. https://doi.org/10.1002/jcop.21914

Myers, N. D., Prilleltensky, I., Prilleltensky, O., Mcmahon, A., Dietz, S., \& Rubenstein, C. L. (2017). Efficacy of the Fun For Wellness Online Intervention to Promote Multidimensional Well-Being: a Randomized Controlled Trial. Prevention Science, 18(8), 984-994. https://doi.org/10.1007/s11121-017-0779-z

Nelson, G, Walsh-Bowers, R., \& Hall, G. (1998). Housing for Psychiatric Survivors: Values, Policy, and Research. Administration and Policy in Mental Health and Mental Health Services Research, 25(4), 455-462. https://doi.org/10.1023/A:1022252826524

Nelson, Geoffrey, Ochocka, J., Griffin, K., \& Lord, J. (1998). "Nothing About Me, Without Me": Participatory Action Research with Self-Help/Mutual Aid Organizations for Psychiatric Consumer/Survivors. American Journal of Community Psychology, 26(6), 881-912. https://doi.org/10.1023/A:1022298129812

Nelson, Geoffrey, Prilleltensky, I., \& Macgillivary, H. (2001). Building Value-Based Partnerships: Toward Solidarity With Oppressed Groups. American Journal of Community Psychology, 29(5), 649-677. https://doi.org/10.1023/A:1010406400101

Nozick, R. (1974). Anarchy, state, and utopia. New York, NY: Basic Books.

O’Connell, M. J., Clayton, A., \& Rowe, M. (2016). Reliability and Validity of a Newly Developed Measure of Citizenship Among Persons with Mental Illnesses. Community Mental Health Journal, 53(3), 367-374. https://doi.org/10.1007/s10597-016-0054-y 
O’Quin, K., \& Vogler, C. C. (1990). Use of the Just World Scale with Prison Inmates: A Methodological Note. Perceptual and Motor Skills, 70(2), 395-400. https://doi.org/10.2466/pms.1990.70.2.395

Ponce, A. N., \& Rowe, M. (2018). Citizenship and Community Mental Health Care. American Journal of Community Psychology, 61(1-2), 22-31. https://doi.org/10.1002/ajcp.12218

Prilleltensky, I, \& Nelson, G. (1997a). Community psychology: Reclaiming social justice. In D. F. \& I. Prilleltensky (Ed.), Critical psychology: An introduction (pp. 166-184). Thousand Oaks, CA: Sage Publications.

Prilleltensky, I, \& Nelson, G. (1997b). Community psychology: Reclaiming social justice. In Fox. D \& P. I. (Eds.), Critical psychology: An introduction (pp. 166-184). London: Sage. Prilleltensky, Isaac. (1994). The Morals and Politics of Psychology: Psychological discourse and the Status Quo. Albany, NY: State University of New York Press.

Prilleltensky, Isaac, Dietz, S., Prilleltensky, O., Myers, N. D., Rubenstein, C. L., Jin, Y., \& McMahon, A. (2015). Assessing multidimensional well-being: development and validation of the I COPPE scale. Journal of Community Psychology, 43(2), 199-226. https://doi.org/10.1002/jcop.21674

Rathus, S. A. (1972). An experimental investigation of assertive training in a group setting. Journal of Behavior Therapy and Experimental Psychiatry, 3(2), 81-86. https://doi.org/10.1016/0005-7916(72)90003-1

Ratts, M. J., Singh, A. A., Nassar-McMillan, S., Butler, S. K., \& McCullough, J. R. (2016). Multicultural and Social Justice Counseling Competencies: Guidelines for the Counseling Profession. Journal of Multicultural Counseling and Development, 44(1), 28-48. https://doi.org/10.1002/jmcd.12035

Reinharz, S. (1984). Alternative settings and social change. (S. R. K. Heller, R. H. Price \& \& 
A. W. S. Riger, Eds.), Psychology and community change. Homewood, IL: Dorsey Press.

Roshani, K., Jalili, S., \& Adaryani, M. M. (2013). Investigating Relational Patterns of Belief in a Just/Unjust World, Satisfaction with Life and Mental Health in Female Students. Current Research Journal of Biological Sciences, 5(3), 136-140.

Rowe, M., \& Davidson, L. (2016). Recovering citizenship. Israel Journal of Psychiatry and Related Sciences, 53(1), 14-21.

Rowe, Michael. (1999). Crossing the Border: Encounters Between Homeless People and Outreach Workers. Berkeley, California: University of California Press.

Rowe, Michael, Benedict, P., Sells, D., Dinzeo, T., Garvin, C., Schwab, L., ... Bellamy, C. (2009). Citizenship, Community, and Recovery: A Group- and Peer-Based Intervention for Persons With Co-Occurring Disorders and Criminal Justice Histories. Journal of $\begin{array}{lllll}\text { Groups in } \quad \text { Addiction } \quad \text { Recovery, } & \text { 4(4), } 244 .\end{array}$ https://doi.org/10.1080/15560350903340874

Rowe, Michael, Clayton, A., Benedict, P., Bellamy, C., Antunes, K., Miller, R., ... O’Connell, M. J. (2012). Going to the source: creating a citizenship outcome measure by communitybased participatory research methods. Psychiatric Services, 63(5), 445-450. https://doi.org/10.1176/appi.ps.201100272

Rowe, Michael, Kloos, B., Chinman, M., Davidson, L., \& Cross, A. B. (2001). Homelessness, Mental Illness and Citizenship. Social Policy and Administration, 35(1), 14-31. https://doi.org/10.1111/1467-9515.00217

Rowe, Michael, \& Pelletier, J.-F. (2012). Citizenship: A Response to the Marginalization of People with Mental Illnesses. Journal of Forensic Psychology Practice, 12(4), 366-381. https://doi.org/10.1080/15228932.2012.697423

Ruffy, M. (1981). Influence of social factors in the development of the young child's moral 
judgment. European Journal of Social Psychology, 11(1), 61-75. https://doi.org/10.1002/ejsp.2420110104

Rushton, J. P., Fulker, D., Neale, M., Nias, D., \& Eysenck, H. (1989). Ageing and the relation of aggression, altruism and assertiveness scales to the Eysenck Personality Questionnaire. Personality and Individual Differences, 10(2), 261-263. https://doi.org/https://doi.org/10.1016/0191-8869(89)90213-4

Ryan, W. (1976). Blaming the Victim. New York, NY: Vintage Books.

Sagiv, L., \& Schwartz, S. H. (2000). Value priorities and subjective well-being: direct relations and congruity effects. European Journal of Social Psychology, 30(2), 177-198. https://doi.org/10.1002/(SICI)1099-0992(200003/04)30:2<177::AID-

EJSP982>3.0.CO;2-Z

Sherrod, L., Flanagan, C., \& Youniss, J. (2002). Dimensions of Citizenship and Opportunities for Youth Development: The What, Why, When, Where, and Who of Citizenship Development. Applied Developmental Science, 6(4), 264-272. https://doi.org/http://dx.doi.org/10.1207/S1532480XADS0604_14

Sherrod, L. R., Flanagan, C., \& Youniss, J. (2010). Dimensions of Citizenship and Opportunities for Youth Development: The What, Why, When, Where, and Who of Citizenship Development. Applied Developmental Science, 6(4), 264-272. https://doi.org/10.1207/S1532480XADS0604_14

Stroebe, K. (2013). Motivated inaction: when collective disadvantage does not induce collective action. Journal of Applied Social Psychology, 43(10), 1997-2006. https://doi.org/10.1111/jasp.12153

Swanson, D. M. (2010). Value in Shadows: A Critical Contribution to Values Education in Our Times. In International Research Handbook on Values Education (pp. 137-152). 
Dordrecht: Springer Netherlands. https://doi.org/10.1007/978-90-481-8675-4_8

Thompson, R. J., \& Berenbaum, H. (2011). Adaptive and Aggressive Assertiveness Scales (AAA-S). Journal of Psychopathology and Behavioral Assessment, 33(3), 323-334. https://doi.org/10.1007/s10862-011-9226-9

Tucker, M. L., \& McCarthy, A. M. (2001). Presentation Self-Efficacy: Increasing Communication Skills Through Service-Learning. Journal of Managerial Issues, 13(2), 227-244. https://doi.org/10.2307/40604346

Valentine, M., \& Capponi, P. (1989). Mental health consumer participation on boards and committees: barriers and strategies. Canada's Mental Health, 37(2), 8-12.

Vera, E. M., \& Speight, S. L. (2003). Multicultural Competence, Social Justice, and Counseling Psychology: Expanding Our Roles. The Counseling Psychologist, 31(3), 253-272. https://doi.org/10.1177/0011000003031003001

Watts, B. E. (2017). Homelessness, Empowerment and Self-reliance in Scotland and Ireland: The Impact of Legal Rights to Housing for Homeless People. Journal of Social Policy, 43(4), 793-810. https://doi.org/10.1017/S0047279414000282

Weddington, W. W. (1995). Soul Searching: Why Psychotherapy Must Promote Moral Responsibility. JAMA: The Journal of the American Medical Association, 274(24), 1968. https://doi.org/10.1001/jama.1995.03530240078049

Welzel, C., \& Inglehart, R. (2010). Agency, Values, and Well-Being: A Human Development Model. Social Indicators Research, 97(1), 43-63. https://doi.org/10.1007/s11205-009$9557-\mathrm{z}$

Whatley, M. A. (1993). Belief in a Just World Scale: Unidimensional or Multidimensional? The Journal of Social Psychology, 133(4), 547-551. https://doi.org/10.1080/00224545.1993.9712180 
Youniss, J., McLellan, J. A., \& Yates, M. (1997). What We Know About Engendering Civic Identity. American Behavioral Scientist, 40(5), 620-631. https://doi.org/10.1177/0002764297040005008

Zaff, J., Boyd, M., Li, Y., Lerner, J. V, \& Lerner, R. M. (2010). Active and Engaged Citizenship: Multi-group and Longitudinal Factorial Analysis of an Integrated Construct of Civic Engagement. Journal of Youth and Adolescence, 39(7), 736-750. https://doi.org/10.1007/s10964-010-9541-6

Zalewska, A., \& Zawadzka, A. (2016). Subjective well-being and Citizenship dimensions according to individualism and collectivism beliefs among Polish adolescents. Current Issues in Personality Psychology, 4(3). https://doi.org/10.5114/cipp.2016.61520 